IRSH 65 (2020), pp. I69-I95 doi:I0.1017/S0020859020000I I

(C) 2020 Internationaal Instituut voor Sociale Geschiedenis

\title{
Runaway Slaves in Antebellum Baltimore: An Urban Form of Marronage?*
}

\author{
Viola Franziska MÜller \\ Department of History and Civilization \\ European University Institute \\ Villa Paola, Via dei Roccettini 9 \\ soor4 San Domenico di Fiesole, FI, Italy
}

E-mail: viola.muller@eui.eu

\begin{abstract}
The starting point of this article is the observation that thousands of enslaved people escaped bondage and managed to find refuge in the city of Baltimore between I 800 and I 860 . There, they integrated into a large free black community. Given the use of the term "urban marronage" to categorize slave flight to cities in some historical literature, this chapter discusses the concept of marronage and its applicability to the urban context of antebellum Baltimore. It examines individual escapees from slavery, the communities they joined, and the broader slaveholding society to emphasize that the interplay and mutual relations of all three should be considered when assessing the applicability of this concept. Discussing the historiography around marronage and the arguments that speak both in favour of and against applying the concept of urban maroons to Baltimore's runaway slaves, this article ultimately dismisses its suitability for this case. In the process, this examination reveals the core of the concept, which, above all, concerns the aspect of resistance. In this context, it will be argued that resistance in the sense of rejecting the control of the dominant society should be included in the general definition of marronage.
\end{abstract}

\section{INTRODUCTION}

On Saturday evening, 2I June i 85 I, near Cockeysville, Maryland, an enslaved man named Ralph Thompson, "aged about 33 years, a bright mulatto, about 5 feet 10 inches in height", decided to take matters into his own hands and claim his liberty, fleeing his legal owner Samuel Moore. One month later, on Monday 2I July, after Thompson "was seen entering Baltimore on

\footnotetext{
* The author would like to extend her gratitude to Mariana Dantas for commenting on an earlier version of this article, as well as to Jorge Díaz Ceballos, Ian Hathaway, and Gašper Jakovac for helping improve the final version. Thanks also to Seth Rockman, who contributed to the original idea. This article is based on research that has received funding from the Netherlands Organisation for Scientific Research (NWO).
} 
Thursday or Friday afternoon last", Moore placed an advertisement in the local newspaper, The Baltimore Sun. "He has an impediment in his speech", and was "wearing blue pantaloons and a white felt ha[t]". Moore described him in a few words and offered the rather low reward of $\$ 3$ "for his recovery

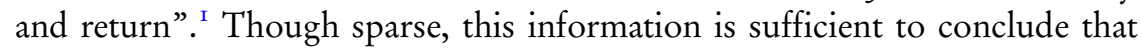
Ralph Thompson was a runaway slave who sought refuge within an urban setting. Some historians have used the term "urban maroon" to categorize people like him - but how appropriate is the term maroon?

Latin Americanists feature most prominently among those who have described slave flight to urban areas as a form of "urban marronage". Historians have labelled runaway slaves hiding in cities cimarrones urbanos (urban maroons), and cities like Havana and Buenos Aires an immense palenque urbano (urban maroon settlement). ${ }^{2}$ In Francophone settings, runaway slaves in cities are likewise claimed to be performing marronnage urbain. ${ }^{3}$ North Americanists and Anglophone scholars have also increasingly applied the term marronage, including in very recent publications. ${ }^{4}$ Simultaneously, there are a number of works that focus on runaway slaves in urban settings, yet do not use the terms maroons and marronage. ${ }^{5}$

Noting these different approaches in scholarship, it is worthwhile taking a close look at the concept of marronage. While this discussion of its definition no doubt contains a great deal of controversy, it should be clear that while all marronage entails the dimension of escape from slavery, not all escapes from slavery should be seen as marronage. So, what are the features that turn some escapees from slavery into maroons and others not? To contribute to a more nuanced understanding, this article examines individual escapees

I. The Baltimore Sun, 2 I July i 85 I.

2. Pedro Deschamps Chapeaux, "Cimarrones urbanos", Revista de la Biblioteca Nacional de Cuba José Martí, 2 (2015), pp. I47, I62, originally published as Los cimarrones urbanos (La Habana, 1983); Eduardo R. Saguier, "La crisis social. La fuga esclava como resistencia rutinaria y cotidiana”, Revista de humanidades y ciencias sociales, r:2 (1995), p. I 25.

3. Jean-Germain Gros, State Failure, Underdevelopment, and Foreign Intervention in Haiti (New York, 2012), p. 72; Aline Helg, Plus jamais esclaves! De l'insoumission à la révolte, le grand récit d'une émancipation (1492-I838) (Paris, 2016), p. 64; Anne Pérotin-Dumon, La ville aux îles, la ville dans l'île. Basse-Terre et Pointe-à-Pitre Guadeloupe, I650-I820 (Paris, 2000), p. 665 .

4. Shauna J. Sweeney, "Market Marronage: Fugitive Women and the Internal Marketing System in Jamaica, I78 I-I 834”, William \& Mary Quarterly, 76:2 (2019), pp. 197-222; Mary Niall Mitchell, "Lurking but Working: City Maroons in Antebellum New Orleans", in Marcus Rediker, Titas Chakraborty, and Matthias van Rossum (eds), A Global History of Runaways: Workers, Mobility, and Capitalism, I600-I850 (Oakland, CA, 2019), pp. I99-2 I 5.

5. José Maia Bezerra Neto, "Histórias urbanas de liberdade. Escravos em fuga na cidade de Belém, I 860-1 888", Afro-Asia, 28 (2002), pp. 22 I-250; Damian Alan Pargas, "Freedom in the Midst of Slavery", in Damian Alan Pargas (ed.), Fugitive Slaves and Spaces of Freedom in North America, I775-I860 (Gainesville, FL, 2018), pp. I16-I36; Viola F. Müller, "Illegal but Tolerated: Slave Refugees in Richmond, Virginia, I800-1860”, in idem, pp. I37-167. 
from slavery, the communities they joined, and the broader slaveholding society to emphasize that the interplay and mutual relations of all three should be taken into consideration.

Historian Steven Hahn has carried out a similar examination, discussing whether some African American communities in the US northern states during the antebellum period (c. I 800-I 860) showed features of a maroon society. While, ultimately, he does not come to an explicit conclusion, he recognizes the value of the concept because it reveals insights into the political consciousness of enslaved and free African Americans. ${ }^{6}$ This article agrees with Hahn, in that marronage is a concept that promises a great many insights into the lives of people of whom we have few first-hand accounts in the historical archives. In cases of very limited self-documentation, we must shift the analysis to group behaviour to draw conclusions about identity and modes of thinking. The concept of marronage can deliver many such insights, but we should have a conversation about how to use it.

Given that publications on slave flight are numerous, and that they increasingly include urban areas as destinations as well, a city will also be the locale of this analysis. Baltimore presents an ideal case for establishing whether runaway slaves and their receiving societies were maroons because, in the antebellum period, it hosted a substantial and growing free black population and continuously attracted runaway slaves. This article will therefore discuss the applicability of the concept of marronage to runaway slaves and their receiving society in the urban context of Baltimore. The first section analyses the historiography of marronage in the Americas. The second introduces the historical context of the city of Baltimore and documents the presence of runaway slaves in the city. The third and fourth sections respectively discuss the arguments that speak in favour of and against marronage in Baltimore. Ultimately, this article dismisses the suitability of the concept of marronage for describing slave flight to Baltimore. However, this examination will reveal the core of the concept. This concerns, above all, the aspect of resistance. In this context, it will be argued that resistance in the sense of rejecting the control of the dominant society should be included in the general definition of marronage.

\section{HISTORIOGRAPHICAL CHALLENGES}

The idea of urban maroons derives from the concept of "conventional" maroons. Historical literature usually defines them as legally enslaved men and

6. Steven Hahn, The Political Worlds of Slavery and Freedom (Cambridge [etc.], 2009), pp. 43-44. Hahn has followed up on Ira Berlin's thought experiment of whether the entire black population of the antebellum northern states of the United States was a maroon community. Ira Berlin, "North of Slavery: Black People in a Slaveholding Republic", Yale, New Haven and American Slavery Conference (26-27 September 2002). Available at: http://www.virginia.edu/woodson/ courses/aas-hius366a/berlin.pdf; last accessed I6 June 2017. 
women in the Americas who escaped slavery by fleeing to remote wilderness areas and securing their freedom. They either formed a settlement with others or joined an existing community. The best-known maroon communities of the Americas were to be found in Jamaica, Brazil, and Suriname, because they posed a threat to colonial authority and, consequently, left a variety of archival traces. This holds particularly true for maroon communities that engaged in warfare or other violent confrontations with the authorities. ${ }^{7}$ Besides, there were also maroons whose existence was less known, but who also enjoyed autonomy and organized themselves separately from dominant white society. For example, Sylviane Diouf explores several US-American maroons in her book Slavery's Exiles. These were slaves who escaped their bonded condition, inhabited wilderness areas on the peripheries or in the general vicinity of plantations and formed groups of different sizes. ${ }^{8}$ These people tried to avoid open confrontation with authorities at all costs.

A number of Latin and North American revisionists have lately started to challenge the emphasis on physical isolation and independence from slaveholding society. These scholars recognize that many maroons did in fact remain in contact with white society (including their fellow bondspeople). ${ }^{9}$ Diouf and Ted Maris-Wolf have shown, in the US-American context, that the grade of isolation experienced by wilderness maroons was not as high as has been hitherto assumed. Especially in the nineteenth century, some wilderness maroons moved into closer contact with the dominant society and were even employed by white people. ${ }^{10}$ For Brazil, historians already claimed in the I 990 s that there had always been interaction and even cooperation between maroons and slaveholding society. ${ }^{\text {II }}$

In order to keep the concept broad, João José Reis and Flávio dos Santos Gomes have suggested that marronage is "flight that led to the formation of

7. This is the conventional concept that prevails within Latin American and Caribbean slavery studies. See Richard Price (ed.), Maroon Societies: Rebel Slave Communities in the Americas (Baltimore, MD [etc.], I979); Alvin O. Thompson, Flight to Freedom: African Runaways and Maroons in the Americas (Kingston, 2006); Glenn Alan Cheney, Quilombo dos Palmares: Brazil's Lost Nation of Fugitive Slaves (Hanover, CT, 2014).

8. Diouf consciously distinguishes runaways and maroons in her study. Sylviane A. Diouf, Slavery's Exiles: The Story of the American Maroons (New York [etc.], 2014), p. 8I.

9. This revision allowed Diouf in the first place to identify many of the protagonists of her study as maroons.

10. Diouf, Slavery's Exiles, pp. 213-2 I 4; Ted Maris-Wolf, "Hidden in Plain Sight: Maroon Life and Labor in Virginia's Dismal Swamp”, Slavery E Abolition, 34:3 (2013), pp. 446-464. Without explicitly challenging the territorial claim of the prevailing concept of marronage, Gwendolyn Midlo Hall, in the early I990s, pointed to maroons working as lumberjacks and supplying white-owned sawmills. Gwendolyn Midlo Hall, Africans in Colonial Louisiana: The Development of Afro-Creole Culture in the Eighteenth Century (Baton Rouge, LA, 1992).

I I. For very contradictory insights into Brazilian quilombos (the Portuguese term for maroon settlement) over the centuries, see João José Reis and Flávio dos Santos Gomes, Liberdade por um fio. História dos quilombos no Brasil (São Paulo, 1996). 
groups of fugitive slaves with whom other social persons frequently associated, [and which] took place in the Americas where slavery flourished" ${ }^{12}$ This definition shifts the focus away from geographical demarcation and pays tribute to the variety among the numerous maroon communities. It does not account for warfare, recognition of autonomy, or cultural aspects. Rather, Reis and Santos Gomes emphasize flight, community, and the continual arrival of newcomers. This approach is helpful because it makes the concept of marronage applicable to different contexts throughout the Americas. However, it runs the risk of inflating the concept by simply equating marronage with slave flight.

These broader definitions have an important linguistic dimension. In Hispanic and Francophone contexts, all runaway slaves are usually called cimarrones or marrons (maroons), respectively. The use of these terms is often based on archival material. In Spanish, for example, the equivalents of runaway slave depots (where runaways were jailed) were depósitos de cimarrones, with the word "maroon" used as a substitute for runaway slave. ${ }^{{ }^{13}}$ In Anglophone settings, however, the application of the concept is not justified by historical sources. Within the United States, Louisiana presents a special case where jail ledgers, up until the mid-nineteenth century, were kept partly in French and in which the terms "runaway slave" and "marron" were used interchangeably. ${ }^{14}$ The issue is that historians often do not sufficiently explain their use of the terms they find in archival sources. Transfers from primary sources as well as translations of scholarship into English often lack a sufficient level of reflection. ${ }^{\mathrm{IS}}$

This linguistic aspect also has another historiographical consequence. Until this day, many historians refer to petit and grand marronage to mark the distinction between runaway slaves who absconded for a short period of time and

I 2. Translation by the author of "A fuga que levava à formação de grupos de escravos fugidos aos quais freqüentemente se associavam outras personagens sociais, acounteceu nas Américas onde vicejou a escravidão". João José Reis and Flávio dos Santos Gomes, "Introdução. Uma História da Liberdade", in Liberdade por um fio, p. Iо. Equally broad, Alvin O. Thompson claimed that marronage "involved both flight from slavery and the establishment of free communities". Thompson, Flight to Freedom, p. I.

I3. For example, D. Joaquin Rodriguez San Pedro (ed.), Legislacion Ultramarina, vol. 3 (Madrid, I865), p. 4I3.

14. Police Jail Daily Reports, I820-1840, New Orleans (LA) Police Jail/Parish Prison, New Orleans Public Library. Moreover, New Orleans authorities faced the phenomenon of both urban runaways within the city and "conventional" marrons in its surroundings. See newspaper coverage, e.g. The Picayune, i 9 July i 837.

I 5. Michel S. Laguerre, Voodoo and Politics in Haiti (New York, I989), p. 72; Sweeney, "Market Marronage”; N.A.T. Hall, "Maritime Maroons: Grand Marronage from the Danish West Indies", William E Mary Quarterly, 42:4 (1985), pp. 476-498; Linda M. Rupert, "Marronage, Manumission and Maritime Trade in the Early Modern Caribbean", Slavery E Abolition, 30:3 (2009), pp. 36I-382; and the English translation of Helg's Plus jamais esclaves: Aline Helg, Slave No More: Self-Liberation before Abolitionism in the Americas (Chapel Hill, NC, 2019). 
those who did so on a long-term or permanent basis. ${ }^{16}$ Although this terminology is likewise rooted in historical documents, namely the writings of the French colonial authorities of the nineteenth century, ${ }^{17}$ its adoption is deeply problematic because it connects a duration to the impact of the action. The implications are manifold. It obscures the original intentions of the people fleeing, shifts the focus away from what happened after they absconded, and ranks the outcome of slave flight as resistance. ${ }^{18}$

Coming back to the urban context, Dennis Cowles has noted the difficulty of including urban runaways into the category of marronage but mistakenly implied that the reason was that urban fugitives did not escape slavery definitively. ${ }^{19}$ His assumption is understandable since historians have only recently begun to engage in depth with long-term and permanent slave flight to urban areas. ${ }^{20}$ Earlier contributions usually approached runaway slaves in cities, located within slaveholding territory, as temporary absconders because it is difficult to find explicit evidence about the length of their presence in the cities. ${ }^{2 \mathrm{I}}$ The argument here is not that urban maroons did not exist, nor that

16. Flávio Gomes, "Africans and Petit Marronage in Rio de Janeiro, ca. I800-1840", Luso-Brazilian Review, 47:2 (2010), pp. 74-99; Mitchell, "Lurking but Working”, p. 203; Marcus P. Nevius, "Lurking about the Neighbourhood: Slave Economy and Petit Marronage in Virginia and North Carolina, 1730 to I 860" (Ph.D., Ohio State University, 2016). See also the contribution by political scientist Neil Roberts, Freedom as Marronage (Chicago, IL, 2015), pp. 98 99. The introduction of this concept into history writing is attributed to Gabriel Debien, "Les origines des esclaves des Antilles", Bulletin de l'IFAN, 27:3-4 (1965), pp. 5-29.

17. Bulletin officiel de l'île Bourbon, vol. 2 (Saint-Denis, I 819; available in the Rare Books section of the Bibliothèque nationale de France), in Jean-Pierre Le Glaunec, "Résister à l'esclavage dans l'Atlantique français. Aperçu historiographique, hypothèses et pistes de recherché", Revue d'histoire de l'Amérique française, 7I:I-2 (2017), p. 7. Available at: https://id.erudit.org/iderudit/ 104278 5ar; last accessed Io October 2019.

I 8. For a critique of the concept of petit and grand marronage, see Le Glaunec, "Résister à l'esclavage", pp. 6-II.

19. Dennis Cowles, "Maroons", in David Head (ed.), Encyclopedia of the Atlantic World, I 4001900: Europe, Africa, and the Americas in an Age of Exploration, Trade, and Empires (Santa Barbara, CA, 2018), p. 393.

20. Bezerra Neto, "Histórias urbanas"; Gomes, "Africans and Petit Marronage;" Pargas, "Freedom in the Midst of Slavery;" Müller, "Illegal but Tolerated;" Mitchell, "Lurking but Working." In the United States, several scholars have earlier noted the phenomenon of permanent urban fugitive slaves but never engaged with it in depth. For example, Peter Kolchin, American Slavery 1619-1877 (New York [etc.], I995), p. I 8; William A. Link, Roots of Secession: Slavery and Politics in Antebellum Virginia (Chapel Hill, NC, 2003), p. 106; Leonard Curry, The Free Black in Urban America, I800-1850: The Shadow of the Dream (Chicago, IL, I98I), p. 4. Michael Zeuske has identified huida urbana (urban flight) in the black neighbourhoods of large Atlantic cities like Havana, Matanzas, New Orleans, and Santiago. Michael Zeuske, Sklavereien, Emanzipationen und atlantische Weltgeschichte. Essays über Mikrogeschichten, Sklaven, Globalisierungen und Rassismus (Leipzig, 2002), p. I46.

$2 \mathrm{r}$. The main work of reference is John Hope Franklin and Loren Schweninger, Runaway Slaves: Rebels on the Plantation (Oxford [etc.], 1999), ch. 6: "They Seek a City". 
maroons never went to the cities, ${ }^{22}$ but rather that we need to thoroughly reflect on what marronage means before we can apply it to the urban context - or not.

These reflections lead us to Leslie Manigat's widely cited definition of marronage. She has claimed that the aspiration of a maroon was "to live, actually free, but as an outlaw, in areas (generally in the woods or in the mountains) where he [or she] could escape the control of the colonial power and the plantocratic establishment". ${ }^{23}$ The aspects of being outlaws and escaping the control of the authorities have often been disregarded in other, broader, definitions, but this is precisely where the strength of the concept lies. Hence this article will take these two points as deserving of closer attention.

The following parts will scan runaway slaves in Baltimore through the lens of marronage, thereby applying Manigat's definition of outlawing and avoidance of control, and the revisionists' call not to focus on geographical location and territorial integrity. It is particularly important to keep in mind that looking at the individuals fleeing does not suffice. Standing alone, slave flight does not tell us enough about the escapee's relation with slaveholding society. ${ }^{24}$ Because marronage has a dimension of identity within the broader community, we must include those who absorb the runaways into the analysis. ${ }^{25}$ The next part, however, will first provide evidence of the presence of runaway slaves in Baltimore.

\section{RUNAWAY SLAVES IN BALTIMORE}

Ralph Thompson, the enslaved man named in the opening paragraph, escaped slavery by running away, joining an existing free black community in Baltimore, and trying to live as de facto free within slaveholding territory.

22. Louisiana maroons, for example, went to the city of New Orleans to sell wood. Diouf, Slavery's Exiles, p. I 22. Brazilian historians might have a point approaching some urban communities as maroons. See Maria Helena Pereira Toledo Machado, "From Slave Rebels to Strikebreakers: The Quilombo of Jabaquara and the Problem of Citizenship in LateNineteenth-Century Brazil", Hispanic American Historical Review, 86:2 (2006), pp. 247-274. In Brazil, historical research is further incentivized by urban communities who keep a maroon identity upright until this day. See Márcia L. A. Souza and Neusa M. M. Gusmão, "Identidade Quilombola e processos educativos presentes num Quilombo urbano. O caso do Quilombo Brotas”, Educação E linguagem, I 4:23/24 (201 I), pp. 75-93.

23. Leslie F. Manigat, "The Relationship between Marronage and Slave Revolts and Revolution in St. Domingue-Haiti", Annals of the New York Academy of Sciences, 292 (1977), pp. 42 I-422.

24. On marronage and identity, see Jorge Díaz Ceballos, "Cimarronaje, jurisdicción y lealtades híbridas en la Monarquía Hispánica”, in Tomás Mantecón (ed.), Dimensiones del conflico. Resistencias, violencia y policía en el mundo urbano (Santander, forthcoming). On marronage as a counter-ideology, see Carlos Aguirre, "Cimarronaje, bandolerismo y desintegración esclavista. Lima, I82I-I854”, in Carlos Aguirre and Charles Walker (eds), Bandoleros, abigeos y Montoneros. Criminalidad y violencia en el Perú, siglos XVIII-XX (Lima, 1990), pp. I 37-i 82.

25. In this context, it is important to recall that maroons could both establish new, independent communities or join existing ones. 
Thompson is not an isolated case. Already during the eighteenth century, but much more markedly during the nineteenth century, runaway slaves gravitated to the growing cities of the southern states in increasing numbers. As is well known, enslaved people also fled to the northern states and places outside the US, where slavery was abolished and freedom could be obtained in official ways. ${ }^{26}$ But their endeavours in southern cities are especially remarkable, because, by staying within the slaveholding South, the freedom these escapees could obtain was of an illegal nature. It had no basis in law but nevertheless allowed them to live as if they were free - just like conventional maroons who went "underground". ${ }^{27}$

Jail statistics and newspaper announcements show that in the early i 830 , the Baltimore City Jail locked up one suspected runaway slave on average every one and a half days. Over the entire course of the antebellum era, newspapers were full of advertisements for runaway slaves believed to be hiding in the city. ${ }^{28}$ Due to its expansion and rapid growth, this article estimates that Baltimore received dozens of them annually in the early nineteenth century and hundreds in the decades before the Civil War. The new and confusing environment of burgeoning cities added to the chances of successful concealment. And for the whole South, historian Richard Wade has claimed that " $t]$ hose living in illegality in the city must have been several times as numerous as those who were discovered". ${ }^{29}$ Although the numbers remained small in comparison to the overall numbers of black residents, and even more so to the total population, the runaway community and their offspring must have amounted to thousands of undocumented city dwellers over the course of the period under analysis.

Baltimore was a thriving commercial city situated on the northern border of the southern states (see Figure I). It grew to be the second largest American city until around I 850 and became the fourth largest by i 860 . Among its 2 I 2,000 inhabitants, 25,700 were free men, women, and children of African descent. This part of the population had grown extensively from 2,700 in I 800 (see Table I). Part of the growth was the result of immigration of refugees from Saint-Domingue following the Haitian Revolution. ${ }^{3 \circ}$ The number of free

26. A very brief selection of contributions includes Leon Litwack, North of Slavery: The Negro in the Free States, I790-I 860 (Chicago, IL, I96I); Daniel G. Hill, Freedom Seekers: Blacks in Early Canada (Toronto, 1992); Eric Foner, Gateway to Freedom: The Hidden History of the Underground Railroad (New York [etc.]: W.W. Norton, 2015); Sean Kelley, "Mexico in His Head: Slavery and the Texas-Mexican Border, г810-1860", Journal of Social History, 37:3 (2004), pp. 709-723.

27. Compare with Manigat, "Relationship between Marronage", pp. 42 I-422.

28. Baltimore City Jail (Runaway Docket), I 836-1 850 , Maryland State Archives (hereafter MSA); for runaway slave ads, see The Baltimore Sun.

29. Richard Wade, Slavery in the Cities: The South $1820-1860$ (New York [etc.], I964), p. 219. 30. Gens de couleur and their slaves might have added thirty per cent to the existing black population of Baltimore. Sherry H. Olson, Baltimore: The Building of an American City (Baltimore, MD [etc.], [1980] 1997), p. 30. 


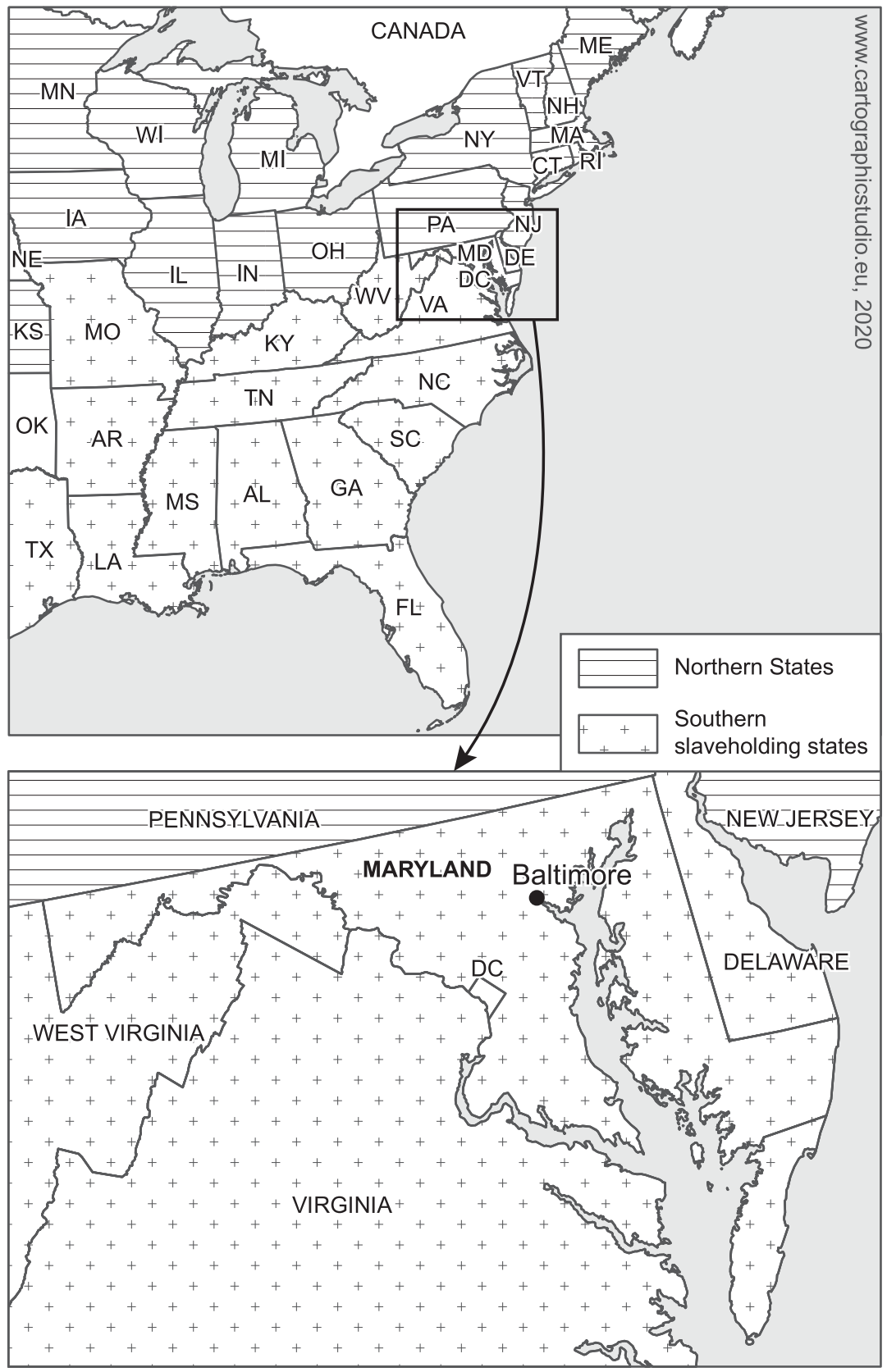

Figure I. Map of the eastern part of the United States, circa I 860. 
Table I. Free African American, enslaved, and total population of Baltimore.

\begin{tabular}{lrrrrrrr}
\hline & 1800 & 1810 & 1820 & 1830 & 1840 & 1850 & 1860 \\
\hline Free black & 2,700 & 5,700 & 10,300 & 14,800 & 18,000 & 25,400 & 25,700 \\
Enslaved & 2,800 & 4,700 & 4,400 & 4,100 & 3,200 & 2,900 & 2,200 \\
Total & 26,500 & 46,600 & 62,700 & 80,600 & 102,300 & 169,100 & 212,400 \\
\hline
\end{tabular}

Sources: US Bureau of the Census, Population of the 100 Largest Cities and Other Urban Places in The United States: 1790 to 1990, available at: https://www.census.gov/ library/working-papers/1998/demo/POP-twps0027.html; last accessed 8 January 2019; US Bureau of the Census, Aggregate Number of Persons within the United States in the Year 1810 (Washington, DC, 1811); DeBow, Seventh Census; US 8th Census, 1860, Population of the United States.

black people in the state of Maryland increased from 8,000 in 1790 to 84,000 by 1860 . At that time, a similar growth and the relative predominance of free black people were to be found only in Latin America and the Caribbean. ${ }^{3 \mathrm{I}}$ By the mid-century, these people were almost exclusively born in the state. ${ }^{32}$ The rapid growth in numbers of free African Americans in Maryland was a legacy of the ideological changes of the revolutionary era, which produced more liberal manumission laws in the Upper South than in the Lower South. ${ }^{33}$ Giving in to the pressures of their slaves, it led hundreds of slaveholders to free their bondspeople, up until approximately $\mathrm{I} 8 \mathrm{I} \circ$, and spurred the autonomous growth of the free black population in the years afterwards. ${ }^{34}$ These were the same developments that led to formal abolitions in the US northern states and throughout the Americas.

Baltimore's location is important, as enslaved African Americans heading to the city from the surrounding counties or further south could also have chosen

3I. J.D.B. DeBow (ed.), The Seventh Census of the United States: I850; Embracing a Statistical View of Each of the States and Territories, Arranged by Counties, Towns, etc., Under the Following Divisions... (Washington, DC, I 853), p. 221; US 8th Census, I860, Population of the United States in I860; Compiled from the Original Returns of the Eighth Census (Washington, DC, 1864), p. 214. See also J.D.B. DeBow, Industrial Resources, Etc. of the Southern and Western States, vol. I (New Orleans, LA, I852), p. 102, cited in Barbara Fields, Slavery and Freedom on the Middle Ground: Maryland during the Nineteenth Century (New Haven, CT [etc.], I985), pp. I-2, 62.

32. Leonard P. Curry, "Free Blacks in the Urban South, I800-1850", Southern Quarterly, 43 (2006), p. 36.

33. Anita Aidt Guy, "The Maryland Abolition Society and the Promotion of the Ideals of the New Nation", Maryland Historical Magazine, 84:4 (1989), p. 342; Ira Berlin, Many Thousands Gone: The First Two Centuries of Slavery in North America (Cambridge [etc.], 1998), pp. 2 I9224. Additional note: The Upper South encompasses Maryland, Delaware, Virginia, North Carolina, Kentucky, Tennessee, and Missouri. The Lower South encompasses South Carolina, Georgia, Florida, Alabama, Mississippi, Arkansas, Louisiana, and Texas.

34. I 8 I 0 was also the year with the highest percentage of black city dwellers in Baltimore. James M. Wright, The Free Negro in Maryland I634-I860 (New York and [etc.], I $92 \mathrm{I}$ ), p. 83. 
the free soil of the North where slavery had been abolished. ${ }^{35}$ Ralph Thompson, for instance, escaped from Cockeysville. From there, the distance to the Pennsylvanian border was almost the same as to Baltimore. A number of reasons, though, encouraged Thompson and others like him to make the choices they made. Employment prospects for black men were better in the southern than in the northern states (in fact, they became better the farther south one went, as demonstrated by Leonard Curry ${ }^{36}$ ), families and friends provided an incentive to stay, and the lack of networks in the North acted as a discouragement.

For example, nineteen-year-old runaway James Harris, with a "very large mouth [and] thick African lips", as his owner described him in an advertisement, could have used his private and work-related network to conceal himself in Fell's Point, a waterfront area in Baltimore. He had lived there prior to his sale and his new owner therefore believed him to be "lurking about that part of the city" in $1842 .{ }^{37}$ Moreover, the information on the timespan of flight that some slaveholders included in the announcements clearly indicates that it was not only temporary absconders who gravitated to Baltimore. To give two examples out of many, a slaveowner knew in I 832 that his bondsman Ben Anderson had "been secreting himself about this city [Baltimore] for three months, passing as a free man" but he was unable to find him. ${ }^{38}$ In I 853, Henry Kemp had already been gone for five months, when his Baltimore master advertised that " $[\mathrm{h}] \mathrm{e}$ is an excellent waiter, and is supposed to be at some large Hotel acting in that capacity". ${ }^{39}$

Historian T. Stephen Whitman has noticed that, from the slaveholders' point of view, the threat of losing a runaway slave to the growing ranks of Baltimore's free black population became more pronounced over time. Maryland slaveowners therefore systematically employed delayed manumissions as a strategy to keep their slaves under control. The idea was that bondspeople, who saw the prospect of becoming legally free in the future, would more willingly surrender to their fate in the present. Control and the impetus to high performance were, hence, important incentives for manumission. In Baltimore, many slaveholders who manumitted slaves out of this logic bought others in the aftermath. This is why the number of manumissions in Maryland was relatively high. Between I790 and I860, 45,000 enslaved people gained

35. This observation contradicts Mary Niall Mitchell who largely dismisses Upper South cities by claiming that it was mostly cities in the Deep South that functioned as places of refuge for runaways. Mitchell, "Lurking but Working”, p. 202.

36. Curry, Free Black in Urban America, ch. 2: "The Most Laborious and Least Profitable Employments: Urban Free Black Occupational Patterns".

37. The Baltimore Sun, I 8 January I 842 .

38. Daily National Intelligencer, 2 I February I 832.

39. The Baltimore Sun, 24 November 1853 . 
their freedom by manumission. ${ }^{40}$ These dynamics led to the highest absolute numbers of free black persons of all the American states and dramatically changed the social worlds of black and white Marylanders. Hundreds of runaways joined the free black population and contributed to its growth.

Despite the higher odds of being legally set free, enslaved men, women, and children from Maryland and other regions in the Upper South were the most severely affected by sale and forced migration. In the nineteenth century, a massive domestic slave trade trafficked bondspeople to the southern and western territories of the expanding republic. Between I790 and I860, approximately one million enslaved people were moved from the Upper to the Lower South. An additional two million were displaced within the same states. ${ }^{4 \mathrm{I}}$ As historians have calculated, between 1830 and I 860 , approximately I 8,500 enslaved men, women, and children were sold out of Maryland. In Baltimore, every third first marriage was broken up, ten to fifteen per cent of enslaved young adults were sold out of state, and one in three children under fifteen years old were separated from at least one parent. ${ }^{42}$

Separating families and uprooting them through forced migrations, the internal slave trade of the nineteenth century was a factor that both aggravated the lives of enslaved people and triggered escapes. Slaveholders were eager to excuse this common practice, which contradicted their claims of being benevolent masters, by blaming the slaves for their own sales. Recounting the story of a free black man in Baltimore whose family was about to be sold to New Orleans, The Baltimore Sun wrote in I850 that "these slaves would have been permitted to have remained here undisturbed for years if all sense of security had not been destroyed by the temptation held out to run away. Every man who owns this kind of property now thinks of hurrying it off further south" ${ }^{43}$ With this opinion, the editor claimed it was the slaves' own fault if they were sold - and he expressed how much of an issue slave flight was.

According to Whitman, many more owners suspected that runaways remained in the city after 1790 . During the I 8 Ios, fugitive slaves were thought to be in that city three to four times more often than in other places. If taking locations close to the city into consideration as well, the share grows even

40. T. Stephen Whitman, "Manumission and Apprenticeship in Maryland, 1770-1870", Maryland Historical Magazine, Iог: (2006), p. 56, in Jessica Millward, “That All Her Increase Shall Be Free': Enslaved Women's Bodies and the Maryland I809 Law of Manumission”, Women's History Review, 21:3 (2012), p. 365; T. Stephen Whitman, The Price of Freedom: Slavery and Manumission in Baltimore and Early National Maryland (Lexington, KY, 1997), pp. 4, 92-94.

4I. Kolchin, American Slavery, p. 96; Damian Alan Pargas, Slavery and Forced Migration in the Antebellum South (New York, 2015), p. 2.

42. Fields, Middle Ground, pp. 8, 17, 33; Michael Tadman, Speculators and Slaves: Masters, Traders, and Slaves in the Old South (Madison, WI, 1989), pp. 5-7, 169-173.

43. The Baltimore Sun, I 2 August 1850. 
more. ${ }^{44}$ Runaway slaves to Baltimore did not usually migrate long distances. As jail records reveal, most were from counties in proximity to the city. Some came from the city itself or from northern Virginia counties. A small number of runaways were caught attempting to return home after being sold further south in the direction of the internal slave trade. ${ }^{45}$ Additionally, some runaways to Baltimore viewed Baltimore as a transit zone, from which to migrate to the free states, even though, as historian Barbara Fields has noted, it was a better place of refuge than a departure point for other safe harbours. ${ }^{46}$

Like other southern cities, Baltimore received two types of runaways: urban (from Baltimore or other cities and towns) and rural. In addition to the challenges all escaped slaves faced, rural runaways had to adapt to an urban economy and become urban workers. Slaves who had experienced greater mobility, for example by having worked as (self-)hired slaves, or who had lived apart from their masters, had clear advantages. Many were used to an autonomous life and the requirements of work in the city. The same mobility described by Jared Hardesty and Marion Pluskota in this issue for eighteenth-century Boston and for the French Caribbean, respectively, also allowed urban bondspeople in the nineteenth-century US South to leave their owners. This was increasingly the case for enslaved people in the southern cities, where the selfhire system came to be an integral part of urban slavery. It holds true even for Baltimore, where slavery had never been strong (see Table I) ${ }^{47}$

To be sure, those who dared to flee enslavement were determined and courageous persons who risked a lot to set themselves free. Runaways who went to Baltimore escaped for very similar reasons as those who became maroons in the classic sense: fear of sale; separation from loved ones; mistreatment; overwork; or the simple conviction that they no longer wanted to be slaves. ${ }^{48}$ As already stated, to determine whether they can be understood as maroons, we

44. T. Stephen Whitman, "Slavery, Manumission, and Free Black Workers in Early National Baltimore” (Ph.D., Johns Hopkins University, I 993), pp. 220-22 I.

45. See "Baltimore City and County Jail Runaway and Accommodations Dockets, I 83 I-I 864 ", in Jerry M. Hynson (ed.), Absconders, Runaways and Other Fugitives in the Baltimore City and County Jail (Westminster, MD, 2004); and "Committed" ads in various newspapers.

46. Fields, Middle Ground, p. 34.

47. Historians have shown that slave hiring had existed during colonial times, too, but the dimensions it assumed in the decades before the Civil War in towns and cities were striking. In the antebellum period, between five and fifteen per cent of the enslaved population were on hire, with an increase closer to the Civil War. In later decades, one third to one half of enslaved people were hired at some point in their lives, at least in parts of the Upper South. John J. Zaborney, Slaves for Hire: Renting Enslaved Laborers in Antebellum Virginia (Baton Rouge, LA, 201 2), pp. I II4; Thomas D. Morris, Southern Slavery and the Law, I6I9-I860 (Chapel Hill, NC, 1996), p. I32; Calvin Schermerhorn, Money over Mastery, Family over Freedom: Slavery in the Antebellum Upper South (Baltimore, MD, $201 \mathrm{I})$, p. I 36.

48. On reasons for becoming a maroon, see Wieke Vink, Creole Jews: Negotiating Community in Colonial Suriname (Leiden, 2010), p. I I4; Christian Delgado Escobar, "Esclavitud, cimarrones y 
must expand the view to include the community they chose to join. As the next two sections will show, arguments exist both for and against applying the concept of marronage to Baltimore's black population.

\section{RESEMBLANCES OF BLACK BALTIMOREANS TO A MAROON COMMUNITY}

Before turning to the points that repudiate the concept of marronage for Baltimore, this section engages with aspects that might lead us to consider black Baltimoreans as maroons in the first place. These include the recruitment of newcomers, solidarity among black people, legal attacks by slaveholding society, and criminalization. ${ }^{49}$

Family networks were an important reason for the significant increase in slave flight to Baltimore in the nineteenth century - despite abolition in the North. People who fled slavery were motivated to stay close to their loved ones. Because manumitted slaves often moved to Baltimore, an increasing number of bondspeople had free family members in the city. In general, their personal networks were broad. Calvin Schermerhorn has laid out that many enslaved families were rooted in this region of the country for several generations. The Chesapeake Bay, home to the city of Baltimore on its northwestern shores, had been one of the pilot projects of African American slavery. Two hundred years after the first enslaved Africans put their feet on soil that would later become the United States, family networks were firm and extended over rural and urban areas. In later times, Schermerhorn stresses, as enslaved families were increasingly broken up and a significant number of slaves experienced greater mobility and more varied employment, these kin networks expanded geographically. ${ }^{\circ}$

It was not only the desire of enslaved people to break free and join their loved ones in Baltimore, the latter also had an incentive in actively supporting slave flight. Through this constant reception of newcomers, the free black community responded to a topic that was a common feature of maroon societies. ${ }^{5 \mathrm{I}}$ Free black people had always been suspected of aiding runaways, but the harbouring of relatives and acquaintances must have worked increasingly well over time. As the nineteenth century progressed, a growing number of enslaved people had friends and relatives who lived in Baltimore, as evidenced by runaway slave advertisements in newspapers. Whereas in the late eighteenth

palenques”, Anacrónica. Revista de los estudiantes de história, 4 (2006). Available at: http://anacronica.univalle.edu.co/esclavitud,_cimarrones_y_palenques.htm; last accessed 9 November 2017. 49. Berlin, "North of Slavery".

50. Schermerhorn, Money over Mastery, pp. I0, 23, 32.

5. See Diouf, Slavery's Exiles, p. 267; Michael Craton, Testing the Chains: Resistance to Slavery in the British West Indies (Ithaca, NY [etc.], I982), p. 78. 
century, a few of these mentioned the family relations of the runaways, ${ }^{52}$ masters later increasingly gave information about the relatives of the absconder and also, in numerous cases, about presumed employment.

Charles A. Pye, the legal owner of the twenty-year-old, "rather handsome", Watt, who left him around I March I816, announced a reward of \$100. "He has some relations at Mr. Foxall's, in Georgetown, and a free brother in Baltimore, where he will probably endeavour to reach. It is likely he will have a pass, as some of his relations read and write", Pye claimed.53 Likewise, enslaved Ellick, eighteen years old, who called himself Alexander Brown, absconded from Jefferson County, (now West) Virginia. His mother lived near Baltimore and his sister in the city. Therefore, his owner believed that he had gone there in I $840 .{ }^{54}$ These and other comparable sources reveal important information about the personal networks of African Americans. As early as the I 830 , free black inhabitants outnumbered the city's enslaved residents by over I0,000, meaning they had more possibilities to shelter and aid runaways. ${ }^{55}$ (For an impression of the size of Baltimore, see Figure 2) These practical aspects combined with the broad social networks increased the willingness to aid runaways from slavery.

Also outside of family structures, black people of different legal statuses showed a remarkable solidarity with each other. For instance, newspapers frequently published advertisements by free black residents claiming to have lost their freedom papers. ${ }^{56}$ Many must have passed them on to slaves who, in turn, could use them to travel to Baltimore and to pass themselves off as free people. Others forged passes for runaways, harboured them, or provided them with contacts to find work. Autobiographer John Thompson, for instance, gave the example of an enslaved man writing passes for other slaves. ${ }^{57}$ Runaway Tom was believed to use the papers of the dead James Lucas to pass himself off as the deceased. ${ }^{8}$ The African American community must not be viewed only as a passive receiving society, but also as an active recruiter of enslaved sisters, husbands, friends, and co-workers.

This loyalty in the black community originated in their shared lived realities but was also affected by material conditions and influenced by broader

52. Robert L. Hall, "Slave Resistance in Baltimore City and County, 1747-1790", Maryland Historical Magazine, 84:4 (1989), p. 306.

53. Baltimore Patriot, I 2 September 18 I6.

54. The Baltimore Sun, 6 August 1840.

55. Christopher Phillips, Freedom's Port: The African American Community of Baltimore, I790I 860 (Urbana, IL, I997), p. 58.

56. For example, "Lost - On Friday last, my FREE PAPERS, (they were in a tin box,) somewhere near the old Fair Grounds. [...] Jas. Brown, A free man of color." Richmond Dispatch, I6 January I86I.

57. John Thompson, The Life of John Thompson, a Fugitive Slave: Containing His History of 25 Years in Bondage, and His Providential Escape. Written by Himself (Worcester, MA, I 856), p. 86. 58. Unknown newspaper, February I 840. 


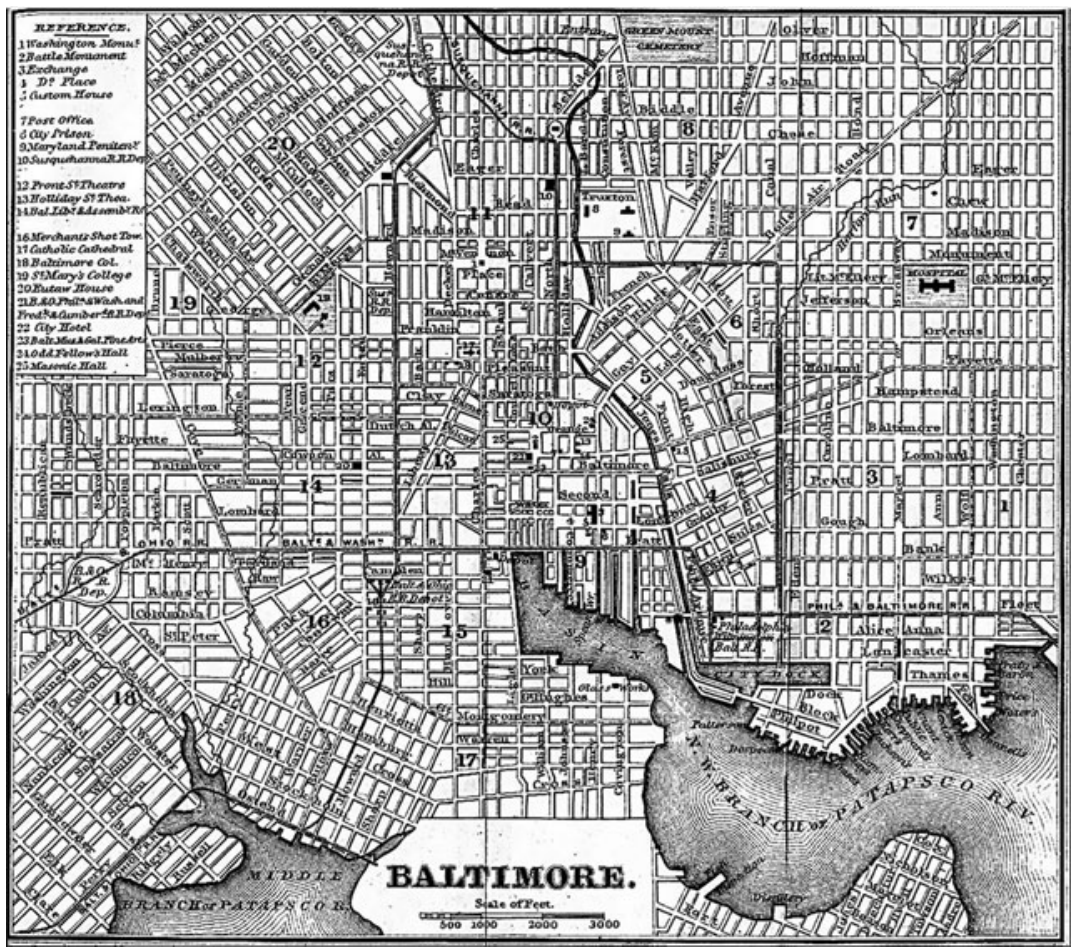

Figure 2. Map of Baltimore, Maryland, I 848.

Source info: Edward H. Hall, Appleton's Hand-Book of American Travel (New York, I869), pp. 298-299. Courtesy of the University of Texas Libraries, University of Texas at Austin.

society. ${ }^{59}$ Solidarity was especially strong in Baltimore, compared to other American places. One of the reasons for this was that, in the Upper South, upward social mobility was almost unachievable for any person of visible African descent, which led to the strengthening of horizontal solidarities and a degree of "racial unity". ${ }^{\circ}$ This unity extended over slavery and freedom because both free and enslaved African Americans came to be treated very

59. Walter Johnson, "Agency: A Ghost Story", in Richard Follett, Eric Foner, and Walter Johnson (eds), Slavery's Ghost: The Problem of Freedom in the Age of Emancipation (Baltimore, MD, 20I I), pp. 28-29.

60. Conversely, Sidney Chalhoub has claimed that slavery in nineteenth-century Brazil allowed for some degrees of social advancement through competition, which had negative effects on the horizontal solidarity amongst the enslaved. Sidney Chalhoub, "The Precariousness of Freedom in a Slave Society (Brazil in the Nineteenth Century)", International Review of Social History, 56:3 (20I I), p. 409. Ira Berlin speaks of racial unity of the black society of the Upper South in comparison to the Lower South. Ira Berlin, Generations of Captivity: A History of African American Slaves (Cambridge, MA, 2003) p. I40. Christopher Phillips notes that there was of course a social 
much alike. Slavery was not only a labour relation and a legal status, it was also a racial order that affected people who stood outside of this institution.

Part of this racial control was that black Baltimoreans were criminalized for actions that did not qualify as offences for white people. For example, black people who did not work in the service of white economic interests could be apprehended and forced to work and their children could be bound out as apprentices. ${ }^{61}$ Since I 83 I, any free black person who moved into Maryland or returned from a trip outside the state could legally be enslaved. Furthermore, free black Marylanders could be sold into slavery for crimes for which whites were punished significantly less harshly. ${ }^{62}$ This befell Thomas Phelps in 1838 , "a mulatto" who "was arraigned for stealing sundry bead bags and a quantity of ribbons and lace" of a value of fifteen dollars. "He was found guilty, and, this being his second offence, he was sentenced to be sold out of the State." ${ }^{33}$ Conventional maroons also faced the constant danger of (re-)enslavement. ${ }^{64}$ This threat of enslavement for free African Americans moved them closer to those already (or still) enslaved. And this proximity was further reinforced by legislation that aimed to define the status and the behaviour of all black people. From I 832 onwards, Baltimore's free blacks started to receive the same punishments for offences as legally enslaved people. The focus on race, rather than legal status, further blurred the distinction between free and enslaved. ${ }^{65}$

Paired with a process of criminalization went a process of systematic illegalization. If black Baltimoreans purchased firearms, liquor, or dogs without a licence, they were criminalized. The same applied to almost everything sold by African Americans without a written permit. When they did it nonetheless, it was seen as illegal. Other institutions, such as black schools and benevolent societies, had to operate clandestinely and were frequently shut down. Significantly, after I 83 I, black people were prohibited from assembling and were required to follow a ro o'clock curfew. ${ }^{66}$ Since black people still had to

stratification within Baltimore's black community, but they were less divided than in other cities and also less divided than Baltimore's white society. Phillips, Freedom's Port, pp. 145-146.

6I. Compare this to the vagrancy laws Marion Pluskota discusses in this issue to force free black people to work.

62. MSA, Archives of Maryland Online, vol. I4 I, Laws of Maryland I 83 I, ch. 323, p. I068; Fields, Middle Ground, p. 79. All materials from Archives of Maryland Online cited in this article can be accessed via http://aomol.msa.maryland.gov/html/index.html. Fields, Middle Ground, p. 79.

63. The Baltimore Sun, i० February I 838 .

64. Berlin, "North of Slavery", pp. 7-8.

65. Baltimore Ordinances, in Wade, Slavery in the Cities, p. 249, 266.

66. MSA, Archives of Maryland Online, vol. I4 I, Laws of Maryland I83 I, ch. 323, p. I068, cited in Hynson, Absconders, p. 61. See also Fields, Middle Ground, p. 35; Ira Berlin, Slaves Without Masters: The Free Negro in the Antebellum South (New York: Pantheon Books, 1974), p. 76. Brazilian scholars have extended this thread to today, comparing favelas to quilombos because of their being "criminalized spaces". Andrelino Campos, Do quilombo à favela. A produção do "espaço criminalizado" no Rio de Janeiro (Lisbon, 2005); Hugo Albuquerque, "Rocinha. O 
survive, they were driven into semi-clandestine or illegal economic and social activities, which meant being driven underground.

Baltimore's free black population also became partly illegalized in itself; this corresponded to the outlawing of maroons. ${ }^{67}$ Although not all maroons lived in illegality, most moved outside the reach of the law and jurisdiction. ${ }^{68}$ The illegalization occurred on various levels. Already in I805, Maryland's General Assembly warned that "great mischiefs have arisen from slaves coming into possession of certificates of free Negroes, by running away and passing as free under the faith of such certificates". Consequently, free black Marylanders were asked to prove their freedom and to acquire corresponding documentation. ${ }^{69}$ From I 824 onwards, manumitted slaves were required to pay a one-dollar fee to receive a certificate of freedom from the clerk of the court. $^{70}$ Those who could not afford the dollar, had a problem and could not prove their freedom without major efforts. In 1832 , another law was enacted requiring slaves manumitted from that year onwards to leave Maryland. This was a response to the violently suppressed Nat Turner rebellion of $183 \mathrm{I}$ in Virginia, which heightened white fears of black people. Legislators knew that the law would not work, because it was a copy of a similar, Virginia law of I 806 , which ordered manumitted slaves out of the state within twelve months of becoming free. ${ }^{71}$ It was nevertheless enacted, first

Quilombo e a Favela”, O Descurvo (20I I). Available at: http://descurvo.blogspot.nl/20I I/I I/ rocinha-o-quilombo-e-favela.html; last accessed 9 November 2017.

67. See Manigat, "Relationship between Marronage", pp. 42 I-422; Monica Schuler, "Maroons (Cimarrones)", in Encyclopedia of Latin American History and Culture (2008). Available at: http://www.encyclopedia.com/humanities/encyclopedias-almanacs-transcripts-and-maps/maroons-cimarrones; last accessed 7 November 2017.

68. Whether the freedom of maroons was illegal or not depended on many factors and could vary over time, for example through truces. For one, the maroons of the Great Dismal Swamp were illegal throughout their existence. The Windward Maroons of Jamaica and the Saramaka from Suriname, by contrast, were granted legal autonomy in exchange for certain concessions. Diouf, Slavery's Exiles; Kenneth M. Bilby, True-Born Maroons (Gainesville, FL, 2008), p. xi; Richard Price, Rainforest Warriors: Human Rights on Trial (Philadelphia, PA [etc.], 20I I), p. 80.

69. Laws of Maryland, I 805 , Ch. 66, in Certificates of Freedom, Guide to Government Records, MSA, 'Descriptions of African American Records'. Available at: http://guide.msa.maryland.gov/ pages/viewer.aspx? page=afridesc; last accessed i 4 December 2019 .

70. Archives of Maryland, Laws of Maryland, I824, ch. 85, vol. I4I, p. 807, cited in Hynson, Absconders, p. 59.

71. General Assembly, “An ACT to amend the several laws concerning slaves” (г 806), transcribed from Samuel Shepherd (ed.), The Statutes at Large of Virginia, from October Session 1792, to December Session I 806 (Richmond, VA, I836), p. 252 , Encyclopedia Virginia (last modified 3 I July 20I 2). Available at: https://www.encyclopediavirginia.org/_An_ACT_to_amend_ the_several_laws_concerning_slaves_i806; last accessed 26 October 2016. In Maryland, it exempted those who were able to convince a "respectable" white person to testify each year that they deserved to remain. MSA, Archives of Maryland Online, vol. I4I, Laws of Maryland I83 I, ch. 28 I, pp. 1035-I04I, extract cited in Fields, Middle Ground, pp. 36-37. 
as a desperate move to convince free African Americans to migrate to Liberia (which eventually proved unsuccessful), and second, because it had the side effect of creating a large population of undocumented people who were stripped of any legal grounds to become politically active. Although there is no evidence of an organized round-up of illegal residents, as happened in Richmond, Virginia, ${ }^{72}$ the law of 1832 attached an illegal status to hundreds of newly freed black people who were not willing to abandon their families and homes. ${ }^{73}$

Like illegalized free black Baltimoreans, runaway slaves depended on anonymity and invisibility before the authorities. This was the nature of the illegal freedom that they could achieve in regions where slavery officially existed. And in Baltimore, they joined a population that faced criminalization and illegalization itself. This does, admittedly, bring the experiences of the city's black community very close to those of maroons, whose freedom was most of the time insecure and fragile. However, there are more factors of marronage to consider. Thus far, it has been shown that Baltimore's black community was discriminated against and excluded. The next section will argue that this exclusion did not stem from the desire of black Baltimoreans and that they, quite contrarily, aspired to inclusion in the dominant society. Hence they were not maroons.

\section{ARGUMENTS AGAINST SEEING BLACK BALTIMOREANS AS A MAROON COMMUNITY}

Slaveholding society usually sees marronage as a threat to the social order. ${ }^{74}$ The measures taken against this threat are often visible in legislative sources. In Maryland, by contrast, the legislative framework developed over time in a way that made it less difficult for runaway slaves to pass as free people, and for their helpers at least not more difficult to shelter or employ them. In the early nineteenth century, in Maryland, as in most other states of the American South, people of African descent were generally supposed to be slaves. ${ }^{75}$ This was problematic when they were taken up as alleged runaway

72. See Carey H. Latimore IV, "A Step Closer to Slavery? Free African Americans, Industrialization, Social Control and Residency in Richmond City, I850-I860", Slavery E Abolition, 33:I (201 2), pp. I 24-I 25.

73. For more on the process of illegalization of African Americans, see Viola F. Müller, "Early Undocumented Workers: Runaway Slaves and African Americans in the Urban South, c.1 $830-$ I 860", Labor History (2019). Available at: https://doi.org/10.1080/0023656X.2019.1649377; last accessed 14 December 2019.

74. Manigat, "Relationship between Marronage”, 425 . Sylviane Diouf has stressed white people's fear of maroons. Diouf, Slavery's Exiles, I7.

75. This remained the case in all southern states except Maryland and Delaware. Berlin, Slaves Without Masters, i 58. 
slaves. If they could not prove their freedom, they ran the risk of being sold into slavery. From I 8 I 7 onwards, however - although discriminating greatly against the free black population (see the previous section) - legislative adjustments made it easier for runaways to succeed in their endeavours - within the state of Maryland, nota bene. ${ }^{76}$

As legal documents show, in 1817 , due to the large numbers of free black inhabitants, the state of Maryland relieved black people of the burden of proof to verify their legal freedom and instead assumed all of them to be free unless proven otherwise. ${ }^{77}$ If a black person jailed as a suspected runaway in Maryland was believed to be free, she or he was to be released and the expenses were levied on the county. In I 824, the General Assembly complained "that Baltimore county is subjected to great annual expense on account of negroes being committed to the jail of that county, on suspicion of being runaway slaves". ${ }^{78}$ The act, however, remained unchanged until the Civil War. In I 83 I, a new law prohibited the hire, employment, or harbouring of illegal free black immigrants to the state, but no mention was made of runaway slaves from Maryland. And although a reward of $\$ 6$ for persons apprehending runaway slaves was made mandatory in I 806 , and increased to $\$ 30$ in I 832 , by I 860 the reward was retracted if the runaways did not remove themselves to a sufficient distance: " $[\mathrm{N}]$ o reward shall be paid under this section for taking up any slave in the county in which said slave is hired, or in which his owner resides". ${ }^{79}$

Additionally, from I 860 on, the commitment of an assumed runaway slave to jail was to be only announced in the Baltimore city papers. Earlier, it was also to be made public in the surrounding areas and in Washington, DC. ${ }^{80}$ Slave flight from Baltimore City or County did not entail a mandatory bounty that would have encouraged uninvolved persons to be on the lookout for the absconder. This is remarkable, especially because it seemed that by the early I 850 , a growing number of runaways taken up in Baltimore were from the city itself. ${ }^{8 \mathrm{I}}$ In I 849 , slaveholders from Maryland's Eastern Shore publicly

76. The following explanations of the relaxation of the legislature against individual runaways within Maryland stood in sharp contrast to the tightening laws regarding white and especially black persons who supported slave flight by enticing away or "stealing" slaves. This corresponded to the major concern about losing slaves beyond state lines.

77. MSA, Archives of Maryland Online, vol. I4I, Laws of Maryland I 817, ch. I I 2, pp. $658 \mathrm{ff}$.

78. Chapter I7I, Laws of I824, in Runaway Docket, Baltimore City and County, Guide to Government Records, MSA, “Descriptions of African American Records”. Available at: http:// guide.msa.maryland.gov/pages/viewer.aspx?page=afridesc; last accessed i4 December 2019 .

79. MSA, Archives of Maryland Online: vol. I92, Session Laws, Nov I806-Jan I807, p. 693; vol. I4I, Laws of Maryland I83 I, ch. 323, p. I068, Laws of Maryland I833, ch. I IL, p. I i I5; vol. I45, Maryland Code i 860 , art. 66, pp. $450-453$.

80. Laws of Maryland, i860, Art. 66, Vol. I45, pp. $450-453$.

8I. Baltimore City Jail (Runaway Docket), I 836-I850, MSA. This observation is in line with Barbara Field's report of Maryland slaveholders who saw a growth in slave flight in the I 8 sos. Fields, Middle Ground, pp. 66-67. 
reproached their bondspeople for fleeing in large numbers: "If something is not done, and that speedily too, there will be but few slaves remaining on the Eastern Shore of Maryland in a few years. They are running off almost daily", lamented a local master. ${ }^{82}$ Sixty slaves allegedly absconded in I 856 alone, and another rash of escapes took place in $1858 .{ }^{83}$ In this context, the calculations by John Hope Franklin and Loren Schweninger are important, as they do not account for an increase in flight to the northern states. ${ }^{84}$ Thus, a large share of fleeing enslaved people must have found themselves in Baltimore. These developments, which spread over the course of the antebellum era, stood in contrast to the common attitudes of legislators towards maroons, who usually tried to implement harsher codes to hamper slave flight. ${ }^{85}$ Legislative relaxation is an indication that legislators did not see runaway slaves within Maryland as a particular threat to the social order.

This observation is also important when it comes to the receiving society in Baltimore. Slavery had many facets and implications, but it was primarily an institution to make some people work for the benefit of other people. In the United States, many white people held the belief that black people were there to serve them. ${ }^{86}$ However, slavery in Baltimore and other cities dramatically decreased. By I 860, the census counted 2,200 enslaved Baltimoreans, who constituted a mere one per cent of the city's total population. ${ }^{87}$ Most slaveholders in the city owned but a single slave. ${ }^{88}$ Quaker Joseph Gurney, who visited Baltimore in the late I 830 , claimed that "the influence of the system [of slavery] on society in general is much limited by the small proportion of slaves". ${ }^{89}$ Yet, institutionalized slavery had another "influence on society" in that it cast a shadow on those who were affected by the same racial order as slaves. Slavery was much more powerful than Gurney assumed.

Early in the century, the abolition of slavery was openly discussed in the Maryland press, in religious congregations, and even by the General Assembly - but the state never brought itself to formally end it. Despite the

82. The Baltimore Sun, 16 October 1849 .

83. This according to James L. Bowers ( 18 I $10-1882$ ), who published two articles discussing slavery in The Cecil Whig on 24 July i 858 . See Accomplice to slave flight, Kent County, Maryland, I 858 , MSA SC 5496-899i. Available at: https://msa.maryland.gov/megafile/msa/speccol/sc5400/ sc5496/008900/00899I/html/00899isources.html; last accessed i4 December 2019.

84. Franklin and Schweninger, Runaway Slaves, p. 279.

85. See, for example, Edward B. Rugemer, Slave Law and the Politics of Resistance in the Early Atlantic World (Cambridge [etc.], 2018), p. I27; Thompson, Flight to Freedom, p. I I 2.

86. For instance, Mia Bay, The White Image in the Black Mind: African-American Ideas about White People, I830-1925 (New York [etc.], 2000), pp. I3-14.

87. US 8th Census, I860, Population of the United States.

88. Fields, Middle Ground, p. 47. This furthermore shows that urban slavery evolved to a largely domestic labour force for those who could afford it. Edward L. Ayers et al., American Passages: A History of the United States, 4 th edn (Boston, MA, 2010), p. I48; Whitman, Price of Freedom.

89. Joseph John Gurney, A Journey in North America, Described in Familiar Letters to Amelia Opie (Norwich, I84I, reprinted in Carlisle, 2007), p. 87. 
subordinate position of slavery in Maryland, however, the new constitution of Maryland of I 85 I, finally, included a prohibition of abolition..$^{\circ}$ The reasons were not of an economic nature, although slavery was still widespread in rural Maryland, especially in wheat agriculture. ${ }^{9^{\mathrm{I}}}$ The argument for the prohibition of abolition is, rather, that the racialized system kept people of African descent in their assigned places.

The fact that the social order white society envisioned was also working well without holding large numbers of black people in legal slavery can be retraced with the statements of anti-black institutions, which changed in tone over time. For example, in I8 I7, the Maryland Colonization Society voiced that free black people had a clear "vicious and mischievous" potential and strongly advocated their removal from the entire country. ${ }^{92}$ Around the same time, the widely read Niles' Weekly Register warned that "free blacks among us are less honest and correct, less industrious and not so much to be depended upon" than slaves. ${ }^{93}$ Free black people in Maryland were seen explicitly as a problem, including being a danger. By the later antebellum period, however, the voices were no longer that strong, and some came to opposite opinions. In I 858 , the governor of Maryland, Thomas H. Hicks, made it clear that where black people "can find employment, chiefly as domestics and laborers, as in her populous city [Baltimore], and in the more thickly settled portions of the State, [...] there is but little of the evil of their vagrancy and idleness felt, not much complaint of its existence". ${ }^{94}$

A year later, the Convention of Maryland Slaveholders likewise showed no interest in removing free African Americans from the state: "[T] he committee came to the conclusion", it reported, "that it was highly inexpedient to undertake any measure for the general removal of our free black population from the State. [...] Their removal from the State would deduct nearly 50 per cent from the household and agricultural labor furnished by people of this color [...]". Instead of enslaving the entire free black population or expelling them from

90. Fields, Middle Ground, pp. 20-2 r. Looking at the entire nation, the number of enslaved people rose from 700,000 in 1790 to four million in 1860 . Return of the Whole Number of Persons within the Several Districts of the United States, According to "An Act Providing for the Enumeration of the Inhabitants of the United States" (Philadelphia, PA, 179I), p. 3; US 8th Census, I860, Population of the United States.

91. The economic orientation towards the North became clear at the latest on the eve of the Civil War when Maryland (together with Missouri, Delaware, and Kentucky) decided that their clinging to slavery was less important than other factors and stayed in the Union.

92. A Letter from Gen. Harper, of Maryland, to Elias B. Caldwell, Esq., Secretary of the American Society for Colonizing the Free People of Colour, in the United States, with Their Own Consent, 20 August I 8 I7 (Baltimore, I8 18), Maryland State Colonization Society Papers, I 827-1 871, Maryland Historical Society, in Whitman, "Slavery and Manumission”, p. 379.

93. Niles' Weekly Register, 22 May i 8 I 9.

94. The Inaugural Address of Thomas H. Hicks, Governor of Maryland, delivered in the Senate Chamber, at Annapolis, Wednesday I 3 January i 858 , MSA. 
the country, it would be better to "make these people orderly, industrious and productive", the slaveholders agreed.9

Whereas contradictory opinions of white people regarding free black people had always existed, the ones in favour of expelling them were markedly less unanimous in the later years of the antebellum period..$^{6}$ The labour aspect, as mentioned by Hicks and the Maryland slaveholders, was very important. Compliance with their own labour exploitation and the subordination free black people displayed were precisely what white society expected from them. Black men and women undertook the most menial work requiring the least skills. Over time, their already precarious socio-economic situation noticeably worsened, and poverty aggravated racial discrimination. ${ }^{97}$ Baltimore was the southern city where black people owned the least property. In I 850 , free black inhabitants who owned property constituted a mere 0.06 per cent of the city's inhabitants..$^{98}$ Remarkably, this was still too much for some white Marylanders. In I 860, the spokesman of the Baltimore convention asked to legally bar black people from purchasing houses or leasing them for more than a year. ${ }^{99}$ Due to racist legislation, free black people had very few resources to resist. Although they were considered persons by law, not property like slaves, their societal, political, and economic opportunities were dramatically limited. In most states, persons of colour were not allowed to vote, to testify in court, or to sit on juries. They were not allowed to freely travel or assemble, nor could they marry whites. Legislative restrictions emphasized political and judicial exclusion. ${ }^{100}$

Steven Hahn has also taken the dimension of exclusion into account. His considerations are of special interest in this last section on points that further reject the application of the concept of marronage to Baltimore. Hahn has examined black communities in the US northern states along demographics, migration patterns, residency, and social and political organization. He points to their internal coherence, social experiences, autonomous institutions, and

95. The Baltimore Sun, го June I 859 . The same Convention of Maryland Slaveholders had just a decade and a half earlier recommended a number of propositions "for the consideration of the legislature", including a "responsible security" free blacks should give to ensure "his or her good behavior". If they absconded from service, they should be sold out of state. The Baltimore Sun, i 8 January i 842.

96. Seth Rockman has even claimed that in Baltimore, there was less racist coverage in the media than elsewhere because black people were too pivotal in the labour market. Seth Rockman, Scraping By: Wage Labor, Slavery, and Survival in Early Baltimore (Baltimore, MD, 2009), p. I 3. 97. On black occupations, see Matchett's Baltimore Director, Corrected up to June I83I. Containing (With, or Without) A Plan of the City; With Reference to the Public Buildings (Baltimore, MD, I83 I), MSA; Curry, Free Black in Urban America, p. 26; Olson, Baltimore.

98. Phillips, Freedom's Port, pp. 98-100, I55.

99. Planter's Advocate, 22 February i 860, in Fields, Middle Ground, p. 79.

I00. A. Leon Higginbotham, Jr, In the Matter of Color: Race and the American Legal Process; The Colonial Period (New York [etc.]: Oxford University Press, 1978), p. 206; Kolchin, American Slavery, pp. 17, 82-84. 
legal background as factors that might qualify them for marronage. ${ }^{\text {IOI }}$ Hahn's view corresponds to the revisionists' call for a reassessment of the physical isolation of maroons. They agree that it is more fruitful to put weight on their social outsider status instead of territorial integrity. ${ }^{102}$ The issue is that while Hahn expressly stresses societal exclusion and autonomous organization as a prominent feature of marronage, he fails to see that this exclusion emanated from white society alone. ${ }^{103}$

African Americans organized themselves independently of white society, through ideology, religion, schools, benevolent societies, and social spaces. In fact, Baltimore's black community established their own religious institutions quite early on. Although severely restricted in many aspects of their lives, free black Baltimoreans had their own official places of worship since the early nineteenth century. The African Methodist Bethel Society was founded in I 8 I 5 , and by 1860 there were sixteen black churches and missions in Baltimore with at least 6,400 registered members who worshipped in their own fashion. This relative autonomy allowed preachers the liberty to interpret the Bible in a way that did more justice to black people's experiences. Moreover, through churches, black communities in different places interacted with each other. The African Methodist Episcopal Church of Baltimore, established in 1816, was connected to those in Philadelphia, Charleston, and New Orleans. ${ }^{104}$

This social exclusion and independent organization, however, did not stem from a desire for demarcation from white society. Rather, it was the secondbest choice black people had after being rejected. There is a considerable amount of literature dedicated to the fight of African Americans to be recognized as equal elements of American society. ${ }^{105}$ Hahn has rightly observed

Ior. Hahn, Political Worlds, pp. 29, 32.

I02. Maris-Wolf, "Hidden in Plain Sight", p. 457.

I03. Hahn, Political Worlds, p. 34. Independent organization of black life indeed corresponds to the day-to-day experiences of maroons. Kevin Olson, Imagined Sovereignties: The Power of the People and Other Myths of the Modern Age (New York, 2016), p. I 27; Marjolein Kars, "Maroons and Marronage”, Oxford Bibliographies (30 August 2016). Available at: http://doi.org/10.1093/ obo/97801997304I4-0229; last accessed is June 2017.

104. Phillips, Freedom's Port, pp. I33, I40-142; Kami Fletcher, "The History of African American Undertakers”, Black Perspectives. Available at: http://www.aaihs.org/the-history-ofafrican-american-undertakers-in-baltimore/; last accessed II July 2017; Albert J. Raboteau, Slave Religion: The "Invisible Institution" in the Antebellum South (Oxford [etc.], 2004), p. 204. Independent organization, however, did not mean that black Baltimoreans were left in peace. Churches operated autonomously, but whites viewed their religious services with suspicion. 105. David Waldstreicher, In the Midst of Perpetual Fetes: The Making of American Nationalism, I776-I820 (Williamsburg, VA, I997), 3 I 7; Mariana L. R. Dantas, Black Townsmen: Urban Slavery and Freedom in the Eighteenth-Century Americas (New York, 2008); Patrick Rael, Black Identity and Black Protest in the Antebellum North (Chapel Hill, NC, 2002), p. 282; Martha S. Jones, Birthright Citizens: A History of Race and Rights in Antebellum America (New York [etc.], 2018). 
that exclusion created spaces to construct new black politics, ${ }^{106}$ yet the fight for citizenship ultimately always dominated black struggle. ${ }^{107}$ Moreover, historian Martha Jones has recently shown for Baltimore that independent black organizations also followed the rules of white society. The very incorporation of the church, the symbolic and literal centre of most black communities, occurred according to official law. Land had to be formally purchased, the church officially registered, an enslaved minister perhaps manumitted. In this process, they became involved with white attorneys, justices of the peace, and clerks. ${ }^{108}$ It is not that black Baltimoreans did not fight to change the system, but they did it from within.

All these are points where Baltimore's free black community palpably diverges from the concept of a maroon society. While many maroon communities had economic ties to slaveholding society as well, they did not integrate as thoroughly into the economic place assigned to them by white society as the majority of black people in Baltimore did. Although they lived in severe poverty, they did not elude the legal reach of society, which drastically discriminated against them. On the one hand, it was a clear improvement for escapees from slavery as they were not under the control of a master. On the other, the loss of individual control gave way to the collective control of the whole African American population. Whereas, as Frederick Law Olmsted, a journalist from the US North, wrote in I 860 that in the countryside, "the security of the whites" depended "upon the constant, habitual, and instinctive surveillance and authority of all white people over all black", ${ }^{\circ 09}$ in the urban context, the authorities took on the matter of social control. ${ }^{\text {IO }}$ Apparently, control by society at large and the restrictions of severe, discriminatory laws was something African Americans could collectively handle, especially in the anonymity of a city.

The compliance with their own subordination was exactly what black activist David Walker criticized in his Appeal to the Coloured Citizens in I 829. ${ }^{\text {II }}$ As historian Stephen Kantrowitz has claimed, rather than challenging the political system and the nation itself, Walker demanded a place in it. ${ }^{\mathrm{II}}$ Maroons, by contrast, would not strive for citizenship in a slaveholding republic. They

I06. Hahn, Political Worlds, p. 43.

107. Jim Cullen, American Dream: A Short History of an Idea that Shaped a Nation (Oxford [etc.], 2003), pp. 64, 82.

I08. Jones, Birthright Citizens, p. I8.

109. Frederick Law Olmsted, Our Slave States, vol. III: A Journey in the Back Country (New York, I 860), p. 444.

I Io. Wade, Slavery in the Cities, p. 40.

I I I. David Walker, Walker's Appeal, in Four Articles; Together with a Preamble, to the Coloured Citizens of the World, but in Particular, and Very Expressly, to Those of the United States of America, Written in Boston, State of Massachusetts, September 28, I829 (Boston, MA, I830).

I 2. Stephen Kantrowitz, More than Freedom: Fighting for Black Citizenship in a White Republic, I829-I889 (New York, 20I 2), pp. 28-29. 
would not vote and not subordinate themselves to the rules and laws of the very people that upheld the slavery they or their co-maroons had escaped from. Sylviane Diouf has neatly summarized that maroons were distinct from runaways in that the latter "refused enslavement but not the larger society, which they wanted to be part of even if they knew it could only be at its periphery". Instead of rejecting its hegemony, they "continued to live under the discriminatory laws of white society, still subservient and controlled". II3 Persons who fled slavery sought physical liberation from bondage and forced labour. For them, freedom meant acknowledgement and acceptance, and the power to decide freely about their private and public lives. ${ }^{\text {I } 4}$ Joining or establishing a maroon community would have provided these privileges. These people, however, abandoned the hopes of being fully accepted into American society.

\section{CONCLUSION}

This article has discussed a number of aspects that speak in favour of and against understanding runaway slaves in Baltimore as maroons and their receiving society as a maroon community. Based on some of the findings, African Americans in Baltimore could well have been a maroon community. They were de facto free people surrounded by slavery, and the community existed at the (not physical) margins of white society. The reception of runaways, a freedom in danger, criminalization of their activities, and illegalization of (parts of) its members were realities conventional maroons also experienced. What contradicts marronage is the view of them by white society and the collective attitude of Baltimore's black population towards their own condition. Those in power came to see them not as a threat, and black Baltimoreans condoned the forms of control and surveillance white society imposed on them. Most important was their desire to be included in the larger society. Because these counterarguments are integral features of the concept of marronage and cannot be disregarded, this article concludes that marronage is not an adequate concept to understand their experiences.

Applying this concept to runaway slaves in Baltimore, however, has provided some insights. By following the footsteps of people fleeing slavery and seeking refuge in the city, it has become apparent that the nature of resistance changed in this process. Individuals absconding from their - legally righteous - enslaved condition were rebels in the truest meaning of the word. Yet, by integrating into Baltimore's black community, runaway slaves turned into assimilated residents who attempted to elevate their status by following the very rules that kept the members of this community at the lowest

I I3. Diouf, Slavery's Exiles, p. 2.

i 14 . Kantrowitz, More than Freedom, p. 85. 
social and economic levels. ${ }^{\text {II }}$ This course is different from the resistance displayed by maroons. In this light, this article hopes to contribute to the way historians use the term marronage. Far from claiming that urban maroons did not exist, it has argued that running away alone is not a sufficient indication to qualify for marronage; we always have to consider the community as a whole. Particularly, the dimension of resistance should also be an (perhaps the most) important measurement to be included in the concept. Maroons made conscious choices to reject the control and hegemony of the larger society over their lives. This element should be part of the generic definition of marronage.

I I s. This article claims to speak only for urban runaway slaves in Baltimore. It is, however, an invitation for scholars working on other periods and regions to more thoroughly investigate the relationship of runaway slaves and their receiving communities with the dominant society. 